\title{
Teknik AHP dengan Kriteria SQM: Studi Kasus Pemilihan Software Pustaka Digital
}

\author{
AHP Technique with SQM As Criteria: \\ A Case Study of Digital Library Software Selection
}

\author{
Agus Prianggono ${ }^{1}$, Anwar Fu'adi ${ }^{2}$, Berlian Juliartha Martin Putra ${ }^{3}$ \\ 1,2,3Pemeliharaan Komputer dan Jaringan, Akademi Komunitas Negeri Pacitan \\ E-mail: ${ }^{1}$ agus@ aknpacitan.ac.id, ${ }^{2}$ anwar@ aknpacitan.ac.id, ${ }^{3}$ berlian@ aknpacitan.ac.id
}

\begin{abstract}
Abstrak
Untuk menunjang kegiatan penyelenggaraan pendidikan di perguruan tinggi, khususnya pengelolaan bahan pustaka diperlukan sebuah alat bantu berupa software pustaka digital. Software jenis ini sudah banyak beredar di pasaran, baik bersifat free open sources maupun proprietary. Ketersediaan berbagai macam pilihan alternatif memunculkan pertanyaan yakni, alternatif mana yang paling ideal untuk perguruan tinggi dengan studi kasus di AKN Pacitan. Untuk menjawab pertanyaan ini, tim peneliti melakukan evaluasi dan perangkingan menggunakan teknik Analytical Hierarchy Process (AHP). Dalam proses AHP, tim peneliti menggunakan kriteria-kriteria yang telah dirumuskan dalam Software Quality Model. Data diperoleh melalui teknik survei dengan instrumen kuisioner yang disebar kepada seluruh sivitas akademika AKN Pacitan. Hasil dari penelitian ini diperoleh bahwa Dspace merupakan software pustaka digital yang paling ideal untuk AKN Pacitan.
\end{abstract}

Kata kunci: Analytical Hierarchy Process, Software Quality Model, Pustaka Digital

\begin{abstract}
To support the educational activity in university, especially to manage digital material, we need a digital library software. This type of software has been widely available in the market, both free open source and proprietary. The availability of various options raises a question, which alternative is the most ideal for university, in this case study AKN Pacitan. To answer this question, the research team conducted an evaluation and ranking options using the Analytical Hierarchy Process (AHP) technique. In the AHP process, the research team used the criteria formulated in the Software Quality Model. The data were obtained through a survey technique with a questionnaire instrument distributed to all AKN Pacitan academicians. The results of this study show that Dspace is the most ideal digital library software for AKN Pacitan.
\end{abstract}

Keywords: Analytical Hierarchy Process, Software Quality Model, Digital Library

\section{PENDAHULUAN}

Dalam rangkaian operasional organisasi terdapat banyak sektor kegiatan, baik kegiatan utama maupun kegiatan penunjang. Rangkaian operasional ini saling menunjang satu dengan lainnya untuk menghasilkan nilai tambah yang menjadi ciri khas keluaran organisasi. Di lingkungan perguruan tinggi seperti AKN Pacitan, kegiatan utama dalam rangkaian operasional ini adalah kegiatan pendidikan. Salah satu kegiatan yang menyokong suksesnya operasional pendidikan adalah pengelolaan pustaka yang dimiliki oleh perguruan tinggi, baik pustaka yang berupa referensi hasil pengadaan ataupun pustaka hasil keluaran kegiatan pendidikan seperti bahan ajar, modul praktikum, laporan penelitian, laporan kegiatan mahasiswa, dan lain sebagainya. Untuk memudahkan pengelolaan pustaka yang dimiliki oleh perguruan tinggi diperlukan sebuah alat bantu berupa software pustaka digital. Pustaka digital yang dapat diakses dari luar kampus lebih efesien dari aspek biaya dan waktu [1]. Software semacam ini sudah banyak tersedia di pasaran. Beberapa alternatifnya antara lain KOHA, BIBLIOTEQ, EVERGREEN, OPENBIBLIO, SLIMS, INVENIO, PMB, OPALS, NEWGENLIB [2]. 
Ketersediaan pilihan-pilihan seperti disebutkan di atas memberikan kebebasan perguruan tinggi untuk mengadopsi. Di sisi lain, ketersediaan pilihan juga memunculkan sebuah permasalahan yang dapat dijadikan objek penelitian yakni alternatif mana yang paling ideal untuk organisasi. Pemilihan software pustaka digital yang tidak relavan bisa mengakibatkan terjadinya migrasi data [3] sehingga tidak efektif dan efesien. Selain itu, pustakawan memegang peranan penting untuk menghubungkan antara perpustakaan dan pemustaka [4] sehingga pemilihan pustaka digital harus memperhatikan sumber daya yang mengakses pustaka digital.

Beberapa penelitian pemilihan pustaka digital telah dilakukan, Gani dkk. mengajukan penelitian pemilihan software repositori perpustakaan untuk Universitas Brawijaya, Universitas Muhammadiyah Malang, dan Universitas Negeri Malang dengan pendekatan kualitatif menggunakan metode studi kasus multi-situs dengan hasil bahwa pemilihan software repositori perlu empat aspek, yaitu sesuai dengan keperluan, memiliki izin pemakaian, dukungan teknis, pelatihan, dokumentasi dan pemeliharaan serta staff yang bertanggung jawab [3]. Hilyah melakukan penelitian pemilihan aplikasi digital library berbasis open source dengan menggunakan metode AHP untuk pengambilan keputusan dalam pemilihan dengan tiga level kriteria yaitu kriteria level 1: teknologi, pengguna dan dukungan pihak pengembang, kriteria level 2: 20 kriteria yang didapatkan dari kelebihan khusus software open source digital library, dan kriteria level 3: Ganesha Digital Library (GDL), Senayan, dan Greenstone. Penelitian menghasilkan Ganesha Digital Library (GDL) terpilih lebih handal dibandingkan Senayan dan Greenstone [5]. Pemilihan software digital library berbasis open source dengan AHP dan TOPSIS juga dilakukan oleh Tsabit dkk., dimana metode tersebut digunakan dengan pengujian dan analisis perhitungan secara manual untuk memilih 4 digital library open source yaitu GDL, Inlislite dan Senayan. FOS Senayan memiliki prioritas pertama untuk terpilih dan metode AHP lebih relavan digunakan dibandingkan dengan TOPSIS [6]. AHP digunakan dalam beberapa penelitian sebagai pendukung keputusan, diantaranya keputusan strategis untuk adopsi e-Commerce [7], penentuan bantuan rumah tidak layak huni menggunakan gabungan MEC dan AHP [8] dan pemilihan dosen pembimbing skripsi [9].

Melalui penelitian ini, tim peneliti mengajukan evaluasi secara ilmiah untuk menentukan pilihan Software Pustaka Digital dengan teknik yang digunakan untuk mengambil keputusan adalah Analytical Hierarchy Process (AHP). Variabel yang digunakan adalah kriteria-kriteria yang ada di dalam Software Quality Model yaitu Functionality, Reliability, Usability, Efficiency, Maintainability, dan Portability sedangkan software pustaka digital yang akan dianalisis Dspace, Greenstone, Eprints dan SliMS.

\section{METODE PENELITIAN}

\subsection{Lokasi Penelitian}

Lokasi penelitian dilakukan di Akademi Komunitas Negeri Pacitan dimana nantinya software terpilih akan diimplementasikan sebagai software pustaka digital.

\subsection{Variabel Penelitian}

Variabel penelitian diperoleh dari kriteria software quality model yaitu :

1. Functionality (Fungsionalitas). Kemampuan perangkat lunak untuk menyediakan fungsi sesuai kebutuhan user dan memuaskan user.

2. Reliability (Kehandalan). Kemampuan perangkat lunak untuk mempertahankan tingkat kinerja tertentu/ performance dari software.

3. Usability (Kebergunaan). Kemampuan perangkat lunak untuk dipahami, dipelajari, digunakan, dan menarik bagi pengguna.

4. Efficiency (Efisiensi). Kemampuan perangkat lunak untuk memberikan kinerja yang sesuai dan relatif terhadap jumlah sumber daya yang digunakan.

5. Maintainability (Pemeliharaan). Kemampuan perangkat lunak untuk dimodifikasi. Modifikasi meliputi koreksi, perbaikan atau adaptasi terhadap perubahan lingkungan, persyaratan, dan spesifikasi fungsional. 
6. Portability (Portabilitas). Kemampuan perangkat lunak untuk ditransfer dari satu lingkungan ke lingkungan lain atau kemampuan software beradaptasi saat digunakan di area tertentu.

\subsection{Populasi dan Sample}

Populasi dalam penelitian ini adalah seluruh tenaga Pendidik dan Kependidikan di AKN Pacitan. Alternatif Software Pustaka Digital yang akan menjadi pilihan untuk diimplementasikan adalah empat alternatif yaitu DSpace, Greenstone, Eprints, dan SLiMS.

\subsection{Instrumen Penelitian}

Instrumen penelitian berupa kuisioner yang disebar ke seluruh populasi tenaga Pendidik dan Kependidikan di AKN Pacitan. Kuisioner menggunakan pertanyaan dari kriteria software quality model dengan skala ordinal.

\subsection{Tahapan Penelitian}

Tahapan-tahapan yang dijalankan dalam penelitian ini, digambarkan dalam blok diagram sebagai berikut:

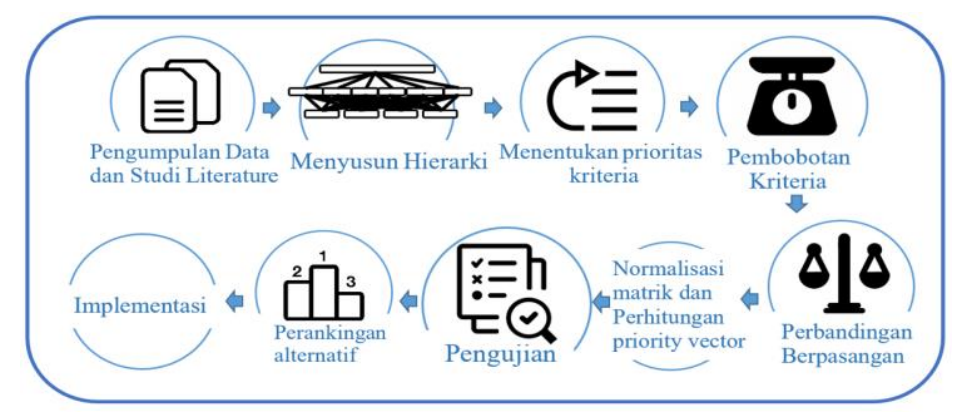

Gambar 1 Blok Diagram Tahapan Penelitian

\section{HASIL DAN PEMBAHASAN}

\subsection{Penentuan Tujuan, Kriteria, dan Alternatif}

Tujuan dari penggunaan teknik AHP dalam penelitian ini adalah melakukan pemilihan terhadap software pustaka digital yang sudah tersedia di pasaran yang paling sesuai dengan kebutuhan sivitas akademika di AKN Pacitan. Proses pemilihan dilakukan dengan menggunakan enam kriteria software quality model seperti dijelaskan pada bagian 2.2. Empat piranti lunak yang menjadi alternatif dalam pemilihan ini diuraikan berdasarkan setiap kriteria sebagai berikut:

\subsubsection{Dspace}

Dspace adalah sebuah platform berbasis open source yang memungkinkan sebuah organisasi untuk mengumpulkan dan mendeskripsikan aset digital melalui sebuah alur kerja yang dapat disesuaikan dengan kebutuhan organisasi. Aset digital yang telah terkumpul dapat didistribusikan menggunakan sebuah web yang dilengkapi dengan sistem pencarian. Dengan demikian aset digital dapat dikelola dan dimanfaatkan untuk jangka waktu yang lama [8].

Fungsionalitas yang dimiliki oleh Dspace antara lain: Akses digital aset secara online meliputi pencarian, dukungan OpenURL dan optimisasi indeks oleh google, Manajemen Metadata, Sistem Workflow yang fleksibel, SWORD Support (Simple Web-service Offering Repository Deposit), OAI Support (Open Archives Initiative), User Management, Pelestarian Digital menggunakan metode checksum. Untuk mendukung reliability, Dspace memiliki fitur Digital Preservation dengan menerapkan Checksum Checker. Penelitian yang dilakukan Jihyun Kim dari University of Michigan School of Information terhadap dua pustaka digital yakni Dspace 
dan Eprints menunjukkan bahwa Dspace memiliki nilai antarmuka yang lebih baik daripada Eprints [9].

Efficiency; kebutuhan hardware minimal untuk menjalankan Dspace dalam lingkungan produksi adalah 2-3 GB RAM dan media penyimpanan 20GB ${ }^{1}$. Maintainability; dokumentasi Dspace yang lengkap mulai dari pemasangan, upgrade, pengadministrasian hingga pengembangan lanjutannya tersedia di https://wiki.lyrasis.org/display/DSPACE. Portability; Proses pemasangan Dspace merupakan yang paling rumit diantara alternatif yang lain. Dalam prosesnya dibutuhkan Apache tomcat, Apache Maven, Apache Ant, serta Yarn untuk mengkompilasi tampilan frontend.

\subsubsection{Greenstone}

Greenstone adalah serangkaian piranti lunak yang digunakan untuk membangun dan mendistribusikan koleksi pustaka digital. Piranti lunak ini menyediakan sebuah cara untuk mengelola dan mempublikasikan pustaka digital dalam bentuk sebuah web atau dalam bentuk media fisik seperti Flash Drive dan DVD. Greenstone dibuat di University of Waikato melalui sebuah proyek bernama New Zealand Digital Library Project [10].

Functionality; pada dasarnya Greenstone merupakan sebuah perkakas yang dapat digunakan untuk membuat pustaka digital. Pustaka digital yang dibangun akan memiliki karakter fully-searchable, metadata-driven. Reliability; Greenstone memiliki kemampuan untuk membangun repositori dalam bentuk media fisik seperti USB Flashdisk atau DVD. Hal ini dapat dimanfaatkan untuk distribusi repositori untuk lokasi-lokasi dengan reliabilitas koneksi yang rendah. Usability; Jesus Tramullas melakukan penelitian terhadap usability dari Greenstone dari tatun 2008-2011. Hasil dari penelitian ini berkesimpulan bahwa antarmuka yang dimiliki oleh Greenstone kurang intuitif. Hal ini diperparah dengan kurangnya support, pembaharuan, serta dokumen referensi yang kurang terorganisasi dengan baik [11].

Efficiency; untuk menjalankan Greenstone, hardware yang dibutuhkan sangan minim yakni komputer dengan prosesor pentium III ataupun pentium $\mathrm{IV}^{2}$. Maintainability; dokumentasi Greenstone yang mulai dari tutorial, customisasi, serta user guide tersedia di http://wiki.greenstone.org/doku.php. Portability; Greenstone didistribusikan dalam bentuk binary, sehingga proses pemasangan dapat dilakukan dengan lumayan mudah dan cepat.

\subsubsection{Eprints}

Eprints adalah piranti lunak repositori berbasis open source yang pertama kali dikembangkan. Eprints dirancang untuk menjadi jembatan informasi yang mengumpulkan luaran penelitian, dengan membuatkan dapat ditemukan, digunakan kembali, serta menyimpannya untuk keperluan di masa yang akan datang [12].

Functionality; Fungsionalitas dari Eprints antara lain penyediaan API untuk integrasi dengan sistem lainnya, pencarian, pengindeksan, dukungan SWORD, Semantic Web, dukungan OAI, XSLT, Workflow, User Management, Task Scheduler, dan flexible object metadata. Reliability; pada Eprints baru diimplementasikan mulai dari Eprints 3. Fitur ini dikerjakan melalui proyek yang terpisah yakni Preserv Project ${ }^{3}$. Fitur ini memungkinkan repository untuk dilakukan pemeliharaan aksesnya melalui jasa profesional penyedia preservasi ${ }^{4}$.

Usability; Pengukuran usability yang dilakukan oleh Ömer Dalkıran di Hacettepe University menunjukkan pengguna merasa nyaman terhadap penggunaan bahasa sistem, kecepatan, dan kemudahan mengakses fitur. Sedangkan user interface mendapat penilaian sedang dari user. Aspek yang mendapat nilai rendah dari user adalah fitur pencaraian yang kurang tepat dan penggunaan terminologi yang kurang umum [13].

\footnotetext{
${ }^{1}$ https://wiki.lyrasis.org/display/DSPACE/User+FAQ

${ }^{2} \mathrm{https} / / /$ silo.tips/download/greenstone-digital-library-software-evaluation\#

${ }^{3}$ http://preserv.Eprints.org/

${ }^{4}$ https://wiki.Eprints.org/w/Preservation_Support
} 
Efficiency; Untuk membuat Eprints berjalan di server produksi dibutuhkan hardware dengan spesifikasi dengan rekomendari minimal 2GB RAM dan ruang penyimpanan $15 \mathrm{~GB}^{5}$. Maintainability; Dokumentasi Eprints yang terdiri dari manual penggunaan, materi training, serta petunjuk konfigurasi tersedia di https://wiki.eprints.org. Portability;Pemasangan Eprints relatif mudah. Pemasangan cukup dilakukan dengan mengunduh kode sumber, mem-build, menginstall, dan membuat repositorinya saja.

\subsubsection{SLiMS}

SLiMS adalah sebuah sistem informasi manajemen yang lengkap untuk perpustakaan. Sistem ini memiliki banyak fitur yang dapat membantu perpustakaan dan pustakawan untuk menyelesaikan tugasnya dengan cepat dan mudah. SLiMS dikembangkan oleh Senayan Developer Community sejak tahun 2007 [12].

Functionality; SLiMS tidak fokus kepada pustaka digital namun merupakan sebuah sistem informasi yang dapat digunakan untuk mengelola perpustakaan. Fitur-fitur yang dimiliki oleh SLiMS antara lain : OPAC, MODS dan JSON-LD format, RSS, OAI-PMH, Copy Cataloguing, Federated Search Engine, Sirkulasi Koleksi, Barcode dan QRCode.

Reliability; untuk menjaga reliabilitas dari Aplikasi SLiMS diperlukan aktifitas pencadangan basis data secara berkala untuk menghindari kehilangan data oleh sebab yang tidak diinginkan. Fitur yang disediakan adalah Backup Database yang dapat diakses admin melalui menu System ${ }^{6}$.

Usability; pengukuran Usability terhadap SLiMS menggunakan metode Checklist dan Think Aloud dilakukan oleh Danang Dwijo Kangko terhadap SLiMS yang digunakan di Perpustakaan BNPB. Pengukuran tersebut menunjukkan hasil bahwa navigasi dinilai kurang terlihat, pencarian spesifik sukar dilakukan, tidak bisa diakses melalui ISBN. Lebih lanjut lagi dijelaskan bahwa kekurangan ini menghasilkan kesan negatif dari pengguna [16].

Efficiency; Untuk dapat menjalankan SLiMS dibutuhkan hardware minimum dengan RAM 4GB dan ruang penyimpanan 500Mb serta dapat menjalankan Apache web server version 2.4, MySQL version 5.7 atau MariaDB version 10.3, PHP version 7.4, PHP GD enabled, PHP gettext enabled, PHP mbstring, berikut dengan phpMyAdmin atau Adminer ${ }^{7}$.

Maintainability; Dokumentasi resmi SLiMS tersedia dalam bahasa Indonesia dan Bahasa Inggris. Dokumen ini tersedia di tautan https://SLiMS.web.id/web/pages/docs/. Portability; pemasangan SLiMS relatif lebih mudah. Kode sumber yang disediakan diletakkan di dalam DocumentRoot sebuah apache web server kemudian siap dijalankan. Bahkan telah disediakan SLiMS dalam bentuk portable dan docker image yang siap untuk production server.

\footnotetext{
${ }^{5}$ https://wiki.Eprints.org/w/Frequently_Asked_Questions

${ }^{6} \mathrm{https} / / /$ sourceforge.net/projects/SLiMS-documentation/files/dokumentasi_SLiMS9_ed2.pdf/download

${ }^{7}$ https://SLiMS.web.id/web/\#section-download
} 


\subsection{Penyusunan Hierarki}

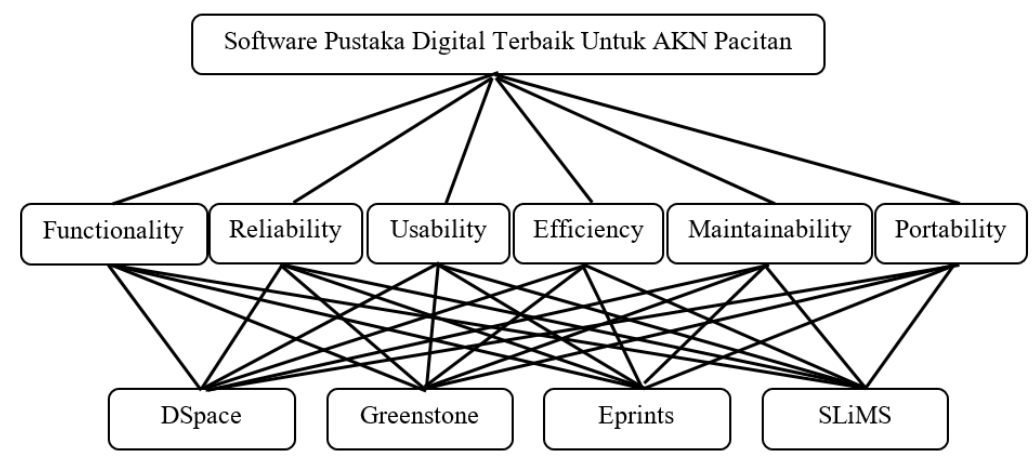

Gambar 2 Blok Diagram Penyusunan Hierarki

\subsection{Pengumpulan Data Prioritas}

Kuisioner yang disebar kepada seluruh civitas akademika di Akademi Komunitas Negeri Pacitan, menghasilkan data berupa pilihan prioritas kriteria software quality model yang diharapkan ada pada software pustaka digital untuk AKN Pacitan. Data jumlah hasil pilihan responden terhadap prioritas kriteria yang diperoleh adalah sebagai berikut:

Tabel 1 Data Jumlah Hasil Pilihan Prioritas

\begin{tabular}{|c|c|c|c|c|}
\hline \multicolumn{2}{|r|}{$\begin{array}{l}\text { Jumlah Responden Memilih } \\
\text { Kriteria } 1\end{array}$} & \multirow{2}{*}{$\begin{array}{c}\begin{array}{c}\text { Jumlah Memilih } \\
\text { Sama Penting }\end{array} \\
2\end{array}$} & \multicolumn{2}{|l|}{$\begin{array}{c}\text { Jumlah Responden Memilih } \\
\text { Kriteria } 2\end{array}$} \\
\hline 13 & Fungsionalitas (Functionality) & & Kehandalan (Reliability) & 7 \\
\hline 10 & Fungsionalitas (Functionality) & 1 & Kebergunaan (Usability) & 11 \\
\hline 10 & Fungsionalitas (Functionality) & 2 & Efisiensi (Efficiency) & 10 \\
\hline 11 & Fungsionalitas (Functionality) & 1 & Pemeliharaan (Maintainability) & 10 \\
\hline 11 & Fungsionalitas (Functionality) & 2 & Portabilitas (Portability) & 9 \\
\hline 10 & Kehandalan (Reliability) & 2 & Fungsionalitas (Functionality) & 10 \\
\hline 7 & Kehandalan (Reliability) & 1 & Kebergunaan (Usability) & 13 \\
\hline 11 & Kehandalan (Reliability) & 2 & Efisiensi (Efficiency) & 9 \\
\hline 12 & Kehandalan (Reliability) & 1 & Pemeliharaan (Maintainability) & 9 \\
\hline 12 & Kehandalan (Reliability) & 3 & Portabilitas (Portability) & 7 \\
\hline 16 & Kebergunaan (Usability) & 2 & Fungsionalitas (Functionality) & 4 \\
\hline 17 & Kebergunaan (Usability) & 1 & Kehandalan (Reliability) & 4 \\
\hline 13 & Kebergunaan (Usability) & 1 & Efisiensi (Efficiency) & 8 \\
\hline 10 & Kebergunaan (Usability) & 1 & Pemeliharaan (Maintainability) & 11 \\
\hline 14 & Kebergunaan (Usability) & 4 & Portabilitas (Portability) & 4 \\
\hline 3 & Efisiensi (Efficiency) & 4 & Fungsionalitas (Functionality) & 15 \\
\hline 6 & Efisiensi (Efficiency) & 3 & Kehandalan (Reliability) & 13 \\
\hline 4 & Efisiensi (Efficiency) & 1 & Kebergunaan (Usability) & 17 \\
\hline 11 & Efisiensi (Efficiency) & 3 & Pemeliharaan (Maintainability) & 8 \\
\hline 10 & Efisiensi (Efficiency) & 5 & Portabilitas (Portability) & 7 \\
\hline \multicolumn{2}{|r|}{$\begin{array}{c}\text { Jumlah Responden Memilih } \\
\text { Kriteria } 1\end{array}$} & $\begin{array}{l}\text { Jumlah Memilih } \\
\text { Sama Penting }\end{array}$ & \multicolumn{2}{|l|}{$\begin{array}{c}\text { Jumlah Responden Memilih } \\
\text { Kriteria } 2\end{array}$} \\
\hline 2 & Pemeliharaan (Maintainability) & 5 & Fungsionalitas (Functionality) & 15 \\
\hline 4 & Pemeliharaan (Maintainability) & 8 & Kehandalan (Reliability) & 10 \\
\hline
\end{tabular}




\begin{tabular}{|c|l|l|l|c|}
\hline 4 & Pemeliharaan (Maintainability) & 1 & Kebergunaan (Usability) & 17 \\
\hline 6 & Pemeliharaan (Maintainability) & 7 & Efisiensi (Efficiency) & 9 \\
\hline 12 & Pemeliharaan (Maintainability) & 3 & Portabilitas (Portability) & 7 \\
\hline 4 & Portabilitas (Portability) & 4 & Fungsionalitas (Functionality) & 14 \\
\hline 4 & Portabilitas (Portability) & 2 & Kehandalan (Reliability) & 16 \\
\hline 4 & Portabilitas (Portability) & 1 & Kebergunaan (Usability) & 17 \\
\hline 4 & Portabilitas (Portability) & 6 & Efisiensi (Efficiency) & 12 \\
\hline 3 & Portabilitas (Portability) & 6 & Pemeliharaan (Maintainability) & 13 \\
\hline
\end{tabular}

Selanjutnya masing-masing kriteria dituliskan dalam kode sebagai berikut :

\begin{tabular}{cl}
\hline Kode & \multicolumn{1}{c}{ Kriteria } \\
\hline K1 & Fungsionalitas (Functionality) \\
\hline K2 & Kehandalan (Reliability) \\
\hline K3 & Kebergunaan (Usability) \\
\hline K4 & Efisiensi (Efficiency) \\
\hline K5 & Pemeliharaan (Maintainability) \\
\hline K6 & Portabilitas (Portability) \\
\hline
\end{tabular}

\subsection{Penentuan Prioritas Kriteria}

Berdasarkan data hasil pilihan prioritas kriteria di atas, selanjutnya dilakukan perbandingan berpasangan terhadap masing-masing kriteria menggunakan rumus :

$$
N P_{(i, j)}=\frac{K_{i}}{K_{j}}
$$

Keterangan : $N P_{(i, j)}=$ Nilai Perbandingan kriteria ke- $i$ dan kriteria ke- $j$

$K_{i} \quad=$ Kriteria ke- $i$ dimana $i=1,2,3, \ldots, n$

$K_{j} \quad=$ Kriteria ke-j dimana $j=1,2,3, \ldots, n$

Berdasarkan data perbandingan kriteria berpasangan, disusunlah matriks perbandingan kriteria sebagai berikut:

Tabel 2 Matriks Perbandingan Kriteria

\begin{tabular}{ccccccc}
\hline $\begin{array}{c}\text { Nilai Perbandingan } \\
\text { Kriteria }\left(N P_{(i, j)}\right)\end{array}$ & K1 & K2 & K3 & K4 & K5 & K6 \\
\hline K1 & 1,00 & 1,86 & 0,85 & 1,00 & 1,20 & 1,22 \\
\hline $\mathbf{K 2}$ & 1,00 & 1,00 & 0,62 & 1,22 & 1,20 & 1,71 \\
\hline $\mathbf{K 3}$ & 4,00 & 3,40 & 1,00 & 1,44 & 0,83 & 3,50 \\
\hline $\mathbf{K 4}$ & 0,20 & 0,46 & 0,29 & 1,00 & 1,38 & 1,43 \\
\hline $\mathbf{K 5}$ & 0,13 & 0,40 & 0,29 & 0,67 & 1,00 & 1,71 \\
\hline $\mathbf{K 6}$ & 0,29 & 0,22 & 0,22 & 0,33 & 0,23 & 1,00 \\
\hline$\left(\Sigma \quad P_{j}\right)$ & $\mathbf{6 , 6 2}$ & $\mathbf{7 , 3 4}$ & $\mathbf{3 , 2 7}$ & $\mathbf{5 , 6 7}$ & $\mathbf{5 , 8 4}$ & $\mathbf{1 0 , 5}$ \\
\hline
\end{tabular}

Keterangan : $\sum \quad P_{j}=$ Jumlah Perbandingan kolom ke- $j$ dimana

$$
j=1,2,3, \ldots, n
$$

\subsection{Pembobotan Kriteria}

Berdasarkan tabel matriks perbandingan kriteria seperti di atas disusunlah pembobotan kriteria menggunakan rumus sebagai berikut: 


$$
N B_{(i, j)}=\frac{N P_{(i, j)}}{\sum P_{j}}
$$

Hasil pembobotan kriteria selanjutnya digunakan sebagai dasar untuk menentukan nilai eigen.

Nilai eigen dihitung menggunakan rumus sebagai berikut :

$$
N E_{i}=\frac{\sum N B_{i}}{n}
$$

Keterangan : $\quad N B_{(i, j)}=$ Nilai Pembobotan baris ke- $i$ kolom ke-j dimana $i=1,2,3, \ldots, n$ dan $j=1,2,3, \ldots, n$

$N E_{i}=$ Nilai Eigen baris ke- $i$ dimana $i=1,2,3, \ldots, n$

$\sum \quad N B_{i}=$ Jumlah Nilai Eigen baris ke- $i$ dimana $i=1,2,3, \ldots, n$

$n \quad=$ Banyaknya Kriteria

Tabel hasil pembobotan kriteria dan perhitungan nilai eigen adalah sebagai berikut :

Tabel 3 Pembobotan Kriteria dan Nilai Eigen

\begin{tabular}{cccccccccc}
\hline $\begin{array}{l}\text { Nilai Pembobotan } \\
\text { Kriteria }\left(N B_{(i, j)}\right)\end{array}$ & $\mathrm{K} 1$ & $\mathrm{~K} 2$ & $\mathrm{~K} 3$ & $\mathrm{~K} 4$ & $\mathrm{~K} 5$ & $\mathrm{~K} 6$ & $\begin{array}{c}\text { Jumlah } \\
\left(\sum\right.\end{array}$ & $\begin{array}{c}\text { Nilai Eigen } \\
\left(N E_{i}\right)\end{array}$ \\
\hline $\mathrm{K} 1$ & 0,15 & 0,23 & 0,29 & 0,17 & 0,18 & 0,12 & 1,14 & 0,19 \\
\hline $\mathrm{K} 2$ & 0,15 & 0,12 & 0,17 & 0,21 & 0,22 & 0,16 & 1,04 & 0,17 \\
\hline $\mathrm{K} 3$ & 0,60 & 0,52 & 0,32 & 0,28 & 0,15 & 0,33 & 2,20 & 0,37 \\
\hline K4 & 0,03 & 0,06 & 0,07 & 0,17 & 0,23 & 0,14 & 0,70 & 0,12 \\
\hline K5 & 0,02 & 0,05 & 0,07 & 0,11 & 0,17 & 0,16 & 0,59 & 0,10 \\
\hline K6 & 0,04 & 0,03 & 0,07 & 0,06 & 0,04 & 0,09 & 0,34 & 0,06 \\
\hline
\end{tabular}

\subsection{Pengujian Konsistensi}

Berdasarkan matriks perbandingan kriteria berpasangan dan tabel pembobotan kriteria, selanjutnya dilakukan pengujian konsistensi terhadap perbandingan yang dilakukan. Hasil pengujian konsistensi memperoleh hasil sebagai berikut:

$$
\begin{aligned}
& \text { Lamda Max }=\sum_{i=1}^{n} \quad\left\{\left(\begin{array}{ll}
\sum & \left.\left.P_{j}\right) \cdot\left(N E_{i}\right)\right\} \\
=(6,62 \times 0,19)+(7,34 \times 0,17)+(3,27 \times 0,37)+(5,67 \times 0,12)+(5,84 \times 0,10)+(10,58 \times 0,06) \\
=5,69 \\
\text { CI } \quad=\frac{\mid \text { Lamda Max }-n \mid}{(n-1)}=\frac{|5,69-6|}{(6-1)}=0,06 \\
\text { IR } \quad=1,24 \\
\text { CR } \quad=\frac{C I}{I R}=0,05
\end{array}\right.\right.
\end{aligned}
$$

Nilai Rasio Konsistensi (CR) dibawah $10 \%$ menunjukkan data perbandingan berpasangan yang diperoleh sudah konsisten.

\subsection{Perbandingan Alternatif}

Penentuan prioritas alternatif piranti lunak dilaksanakan mengikuti proses yang sama dengan penentuan prioritas kriteria. Untuk selanjutnya masing-masing alternatif dituliskan dalam kode sebagai berikut : 
Kode Kriteria

Al1 Dspace

A12 Greenstone

Al3 Eprints

Al4 SLiMS

Proses penentuan prioritas alternatif piranti lunak dilakukan dengan melakukan perbandingan berpasangan alternative untuk setiap kriteria. Adapun proses yang dilakukan adalah sebagai berikut:

A. Functionality

Tabel 4 Matriks Perbandingan dan Pembobotan Nilai Alternatif untuk Kriteria Functionality

\begin{tabular}{|c|c|c|c|c|c|c|c|c|c|c|}
\hline \multirow{3}{*}{$\begin{array}{l}\text { Functionalit } \\
\mathbf{y}\end{array}$} & \multicolumn{4}{|c|}{ Matriks Perbandingan } & \multicolumn{6}{|c|}{ Pembobotan Nilai Alternatif } \\
\hline & \multirow{2}{*}{ Al1 } & \multirow{2}{*}{$\mathrm{A} 12$} & \multirow{2}{*}{$\mathrm{Al} 3$} & \multirow{2}{*}{ Al4 } & \multirow{2}{*}{ Al1 } & \multirow{2}{*}{$\mathrm{A} 12$} & \multirow{2}{*}{$\mathrm{Al} 3$} & \multirow{2}{*}{ Al4 } & Jumlah & \multirow{2}{*}{$\begin{array}{l}\text { Nilai Eigen } \\
\quad\left(N E_{i}\right)\end{array}$} \\
\hline & & & & & & & & & $\left(\sum \quad N B\right.$ & \\
\hline Al1 & $\begin{array}{c}1,0 \\
0\end{array}$ & 7,00 & $\begin{array}{c}3,0 \\
0\end{array}$ & 9,00 & $\begin{array}{c}0,6 \\
3\end{array}$ & $\begin{array}{c}0,6 \\
2\end{array}$ & $\begin{array}{c}0,6 \\
6\end{array}$ & $\begin{array}{c}0,5 \\
0\end{array}$ & 2,41 & 0,60 \\
\hline $\mathrm{A} 12$ & $\begin{array}{c}0,1 \\
4\end{array}$ & 1,00 & $\begin{array}{c}0,3 \\
3\end{array}$ & 3,00 & $\begin{array}{c}0,0 \\
9\end{array}$ & $\begin{array}{c}0,0 \\
9\end{array}$ & $\begin{array}{c}0,0 \\
7\end{array}$ & $\begin{array}{c}0,1 \\
7\end{array}$ & 0,42 & 0,10 \\
\hline $\mathrm{Al} 3$ & $\begin{array}{c}0,3 \\
3\end{array}$ & 3,00 & $\begin{array}{c}1,0 \\
0\end{array}$ & 5,00 & $\begin{array}{c}0,2 \\
1\end{array}$ & $\begin{array}{c}0,2 \\
6\end{array}$ & $\begin{array}{c}0,2 \\
2\end{array}$ & $\begin{array}{c}0,2 \\
8\end{array}$ & 0,97 & 0,24 \\
\hline Al4 & $\begin{array}{c}0,1 \\
1\end{array}$ & 0,33 & $\begin{array}{c}0,2 \\
0\end{array}$ & 1,00 & $\begin{array}{c}0,0 \\
7\end{array}$ & $\begin{array}{c}0,0 \\
3\end{array}$ & $\begin{array}{c}0,0 \\
4\end{array}$ & $\begin{array}{c}0,0 \\
6\end{array}$ & 0,20 & 0,05 \\
\hline$\left(\begin{array}{ll}\Sigma & P_{j}\end{array}\right)$ & $\begin{array}{c}1,5 \\
8\end{array}$ & $\begin{array}{c}11,3 \\
3\end{array}$ & $\begin{array}{c}4,5 \\
3\end{array}$ & $\begin{array}{c}18,0 \\
0\end{array}$ & & & & & & \\
\hline
\end{tabular}

Pengujian konsistensi perbandingan alternatif untuk kriteria Fungsionality :

$$
\begin{array}{lll}
\text { Lamda Max } & =0,95+1,18+1,10+0,89=4,13 \\
\text { CI } & =0,04 \\
\text { IR } & =0,90 \\
\text { CR } & =0,05
\end{array}
$$

\begin{tabular}{|c|c|c|c|c|c|c|c|c|c|c|}
\hline \multirow{3}{*}{ Reliability } & \multicolumn{4}{|c|}{ Matriks Perbandingan } & \multicolumn{6}{|c|}{ Pembobotan Nilai Alternatif } \\
\hline & \multirow{2}{*}{ Al1 } & \multirow{2}{*}{$\mathrm{A} 12$} & \multirow{2}{*}{$\mathrm{A} 13$} & \multirow{2}{*}{ Al4 } & \multirow{2}{*}{ Al1 } & \multirow{2}{*}{$\mathrm{A} 12$} & \multirow{2}{*}{$\mathrm{Al} 3$} & \multirow{2}{*}{ Al4 } & Jumlah & \multirow{2}{*}{$\begin{array}{l}\text { Nilai Eigen } \\
\qquad\left(N E_{i}\right)\end{array}$} \\
\hline & & & & & & & & & $\left(\sum \quad N B_{i}\right.$ & \\
\hline Al1 & $\begin{array}{c}1,0 \\
0\end{array}$ & 7,00 & $\begin{array}{c}5,0 \\
0\end{array}$ & $\begin{array}{c}5,0 \\
0\end{array}$ & $\begin{array}{c}0,6 \\
5\end{array}$ & $\begin{array}{c}0,5 \\
8\end{array}$ & $\begin{array}{c}0,6 \\
8\end{array}$ & $\begin{array}{c}0,6 \\
3\end{array}$ & 2,54 & 0,63 \\
\hline $\mathrm{A} 12$ & $\begin{array}{c}0,1 \\
4 \\
\end{array}$ & 1,00 & $\begin{array}{c}0,3 \\
3 \\
\end{array}$ & $\begin{array}{c}1,0 \\
0\end{array}$ & $\begin{array}{c}0,0 \\
9\end{array}$ & $\begin{array}{c}0,0 \\
8 \\
\end{array}$ & $\begin{array}{c}0,0 \\
5\end{array}$ & $\begin{array}{c}0,1 \\
3 \\
\end{array}$ & 0,34 & 0,09 \\
\hline $\mathrm{A} 13$ & $\begin{array}{c}0,2 \\
0\end{array}$ & 3,00 & $\begin{array}{c}1,0 \\
0\end{array}$ & $\begin{array}{c}1,0 \\
0\end{array}$ & $\begin{array}{c}0,1 \\
3\end{array}$ & $\begin{array}{c}0,2 \\
5\end{array}$ & $\begin{array}{c}0,1 \\
4\end{array}$ & $\begin{array}{c}0,1 \\
3\end{array}$ & 0,64 & 0,16 \\
\hline Al4 & $\begin{array}{c}0,2 \\
0\end{array}$ & 1,00 & $\begin{array}{c}1,0 \\
0\end{array}$ & $\begin{array}{c}1,0 \\
0\end{array}$ & $\begin{array}{c}0,1 \\
3\end{array}$ & $\begin{array}{c}0,0 \\
8\end{array}$ & $\begin{array}{c}0,1 \\
4\end{array}$ & $\begin{array}{c}0,1 \\
3\end{array}$ & 0,47 & 0,12 \\
\hline$\left(\begin{array}{ll}\Sigma & P_{j}\end{array}\right)$ & $\begin{array}{c}1,5 \\
4\end{array}$ & $\begin{array}{c}12,0 \\
0\end{array}$ & $\begin{array}{c}7,3 \\
3\end{array}$ & $\begin{array}{c}8,0 \\
0\end{array}$ & & & & & & \\
\hline
\end{tabular}

B. Reliability

Tabel 5 Matriks Perbandingan dan Pembobotan Nilai Alternatif untuk Kriteria Reliability 
Pengujian konsistensi perbandingan alternatif untuk kriteria Reliability :

$$
\begin{array}{lll}
\text { Lamda Max } & =0,98+1,03+1,18+0,95=4,14 \\
\text { CI } & =0,05 \\
\text { IR } & =0,90 \\
\text { CR } & =0,05
\end{array}
$$

\begin{tabular}{|c|c|c|c|c|c|c|c|c|c|c|}
\hline \multirow{3}{*}{$\begin{array}{c}\text { Usabilit } \\
\mathbf{y}\end{array}$} & \multicolumn{4}{|c|}{ Matriks Perbandingan } & \multicolumn{6}{|c|}{ Pembobotan Nilai Alternatif } \\
\hline & \multirow[b]{2}{*}{ Al1 } & \multirow[b]{2}{*}{$\mathrm{Al} 2$} & \multirow[b]{2}{*}{$\mathrm{Al} 3$} & \multirow[b]{2}{*}{$\mathrm{Al} 4$} & \multirow[b]{2}{*}{ Al1 } & \multirow[b]{2}{*}{$\mathrm{A} 12$} & \multirow[b]{2}{*}{$\mathrm{Al} 3$} & \multirow[b]{2}{*}{$\mathrm{A} 14$} & \multirow[t]{2}{*}{ Jumlah } & \multirow{2}{*}{$\begin{array}{l}\text { Nilai } \\
\text { Eigen } \\
\left(N E_{i}\right) \\
\end{array}$} \\
\hline & & & & & & & & & & \\
\hline Al1 & $\begin{array}{c}1,0 \\
0\end{array}$ & 9,00 & $\begin{array}{c}5,0 \\
0\end{array}$ & $\begin{array}{c}5,0 \\
0\end{array}$ & $\begin{array}{c}0,6 \\
6\end{array}$ & $\begin{array}{c}0,4 \\
5\end{array}$ & $\begin{array}{c}0,6 \\
9\end{array}$ & $\begin{array}{c}0,6 \\
9\end{array}$ & 2,50 & 0,63 \\
\hline $\mathrm{A} 12$ & $\begin{array}{c}0,1 \\
1 \\
\end{array}$ & 1,00 & $\begin{array}{c}0,2 \\
0 \\
\end{array}$ & $\begin{array}{c}0,2 \\
0 \\
\end{array}$ & $\begin{array}{c}0,0 \\
7 \\
\end{array}$ & $\begin{array}{c}0,0 \\
5\end{array}$ & $\begin{array}{c}0,0 \\
3 \\
\end{array}$ & $\begin{array}{c}0,0 \\
3 \\
\end{array}$ & 0,18 & $\mathbf{0 , 0 4}$ \\
\hline $\mathrm{A} 13$ & $\begin{array}{c}0,2 \\
0 \\
\end{array}$ & 5,00 & $\begin{array}{c}1,0 \\
0\end{array}$ & $\begin{array}{c}1,0 \\
0\end{array}$ & $\begin{array}{c}0,1 \\
3 \\
\end{array}$ & $\begin{array}{c}0,2 \\
5\end{array}$ & $\begin{array}{c}0,1 \\
4 \\
\end{array}$ & $\begin{array}{c}0,1 \\
4 \\
\end{array}$ & 0,66 & $\mathbf{0 , 1 7}$ \\
\hline $\mathrm{A} 14$ & $\begin{array}{c}0,2 \\
0 \\
\end{array}$ & 5,00 & $\begin{array}{c}1,0 \\
0 \\
\end{array}$ & $\begin{array}{c}1,0 \\
0 \\
\end{array}$ & $\begin{array}{c}0,1 \\
3 \\
\end{array}$ & $\begin{array}{c}0,2 \\
5 \\
\end{array}$ & $\begin{array}{c}0,1 \\
4 \\
\end{array}$ & $\begin{array}{c}0,1 \\
4 \\
\end{array}$ & 0,66 & $\mathbf{0 , 1 7}$ \\
\hline$\sum_{\quad} P_{j}$ & $\begin{array}{c}1,5 \\
1\end{array}$ & $\begin{array}{c}20,0 \\
0\end{array}$ & $\begin{array}{c}7,2 \\
0\end{array}$ & $\begin{array}{c}7,2 \\
0\end{array}$ & & & & & & \\
\hline
\end{tabular}

C. Usability

Tabel 6 Matriks Perbandingan dan Pembobotan Nilai Alternatif untuk Kriteria Usability

Pengujian konsistensi perbandingan alternatif untuk kriteria Usability :

$$
\begin{array}{ll}
\text { Lamda Max } & =0,94+0,89+1,19+1,19=4,21 \\
\text { CI } & =0,07 \\
\text { IR } & =0,90 \\
\text { CR } & =0,08
\end{array}
$$

\begin{tabular}{|c|c|c|c|c|c|c|c|c|c|c|}
\hline \multirow{3}{*}{$\begin{array}{l}\text { Efficienc } \\
\mathbf{y}\end{array}$} & \multicolumn{4}{|c|}{ Matriks Perbandingan } & \multicolumn{6}{|c|}{ Pembobotan Nilai Alternatif } \\
\hline & \multirow[b]{2}{*}{ Al1 } & \multirow[b]{2}{*}{$\mathrm{Al} 2$} & \multirow[b]{2}{*}{$\mathrm{A} 13$} & \multirow[b]{2}{*}{ Al4 } & \multirow[b]{2}{*}{ Al1 } & \multirow[b]{2}{*}{$\mathrm{A} 12$} & \multirow[b]{2}{*}{$\mathrm{A} 13$} & \multirow[b]{2}{*}{ Al4 } & Jumlah & \multirow{2}{*}{$\begin{array}{l}\text { Nilai Eigen } \\
\quad\left(N E_{i}\right)\end{array}$} \\
\hline & & & & & & & & & $\left(\sum \quad N B_{i}\right.$ & \\
\hline \multirow{2}{*}{ Al1 } & \multirow{2}{*}{1,00} & 0,2 & 0,3 & 0,1 & 0,0 & 0,0 & 0,1 & 0,0 & \multirow{2}{*}{0,26} & \multirow{2}{*}{0,06} \\
\hline & & 0 & 3 & 4 & 6 & 4 & 0 & 6 & & \\
\hline \multirow{2}{*}{$\mathrm{A} 12$} & \multirow{2}{*}{5,00} & 1,0 & 1,0 & 0,3 & 0,3 & 0,1 & 0,3 & 0,1 & \multirow{2}{*}{0,94} & \multirow{2}{*}{$\mathbf{0 , 2 3}$} \\
\hline & & 0 & 0 & 3 & 1 & 9 & 0 & 3 & & \\
\hline \multirow{2}{*}{$\mathrm{A} 13$} & \multirow{2}{*}{3,00} & 1,0 & 1,0 & 1,0 & 0,1 & 0,1 & 0,3 & 0,4 & \multirow{2}{*}{1,08} & \multirow{2}{*}{0,27} \\
\hline & & 0 & 0 & 0 & 9 & 9 & 0 & 0 & & \\
\hline \multirow{2}{*}{$\mathrm{A} 14$} & \multirow{2}{*}{7,00} & 3,0 & 1,0 & 1,0 & 0,4 & 0,5 & 0,3 & 0,4 & \multirow{2}{*}{1,72} & \multirow{2}{*}{$\mathbf{0 , 4 3}$} \\
\hline & & 0 & 0 & 0 & 4 & 8 & 0 & 0 & & \\
\hline$(\Sigma) P_{j}$ & 16,0 & 5,2 & 3,3 & 2,4 & & & & & & \\
\hline ) & 0 & $\mathbf{0}$ & 3 & 7 & & & & & & \\
\hline
\end{tabular}

D. Efficiency

Tabel 7 Matriks Perbandingan dan Pembobotan Nilai Alternatif untuk Kriteria Efficiency

Pengujian konsistensi perbandingan alternatif untuk kriteria Efficiency :

$$
\begin{array}{ll}
\text { Lamda Max } & =1,03+1,22+0,90+1,06=4,21 \\
\text { CI } & =0,07 \\
\text { IR } & =0,90
\end{array}
$$


CR

$=0,08$

E. Maintainability

Tabel 8 Matriks Perbandingan dan Pembobotan Nilai Alternatif untuk Kriteria Maintainability

\begin{tabular}{|c|c|c|c|c|c|c|c|c|c|c|}
\hline \multirow{3}{*}{$\begin{array}{l}\text { Maintainabilit } \\
\mathbf{y}\end{array}$} & \multicolumn{4}{|c|}{ Matriks Perbandingan } & \multicolumn{6}{|c|}{ Pembobotan Nilai Alternatif } \\
\hline & \multirow[b]{2}{*}{ Al1 } & \multirow[b]{2}{*}{$\mathrm{A} 12$} & \multirow[b]{2}{*}{$\mathrm{Al} 3$} & \multirow[b]{2}{*}{ Al4 } & \multirow[b]{2}{*}{ Al1 } & \multirow[b]{2}{*}{$\mathrm{A} 12$} & \multirow[b]{2}{*}{$\mathrm{Al} 3$} & \multirow[b]{2}{*}{$\mathrm{Al} 4$} & Jumlah & \multirow{2}{*}{$\begin{array}{l}\text { Nilai } \\
\text { Eigen } \\
\left(N E_{i}\right)\end{array}$} \\
\hline & & & & & & & & & $\left(\sum \quad N B_{i}\right.$ & \\
\hline Al1 & $\begin{array}{c}1,0 \\
0\end{array}$ & 7,00 & $\begin{array}{c}3,0 \\
0\end{array}$ & $\begin{array}{c}0,3 \\
3\end{array}$ & $\begin{array}{c}0,2 \\
2\end{array}$ & $\begin{array}{c}0,3 \\
9\end{array}$ & $\begin{array}{c}0,3 \\
2\end{array}$ & $\begin{array}{c}0,2 \\
0\end{array}$ & 1,13 & 0,28 \\
\hline $\mathrm{A} 12$ & $\begin{array}{c}0,1 \\
4\end{array}$ & 1,00 & $\begin{array}{c}0,3 \\
3\end{array}$ & $\begin{array}{c}0,1 \\
4\end{array}$ & $\begin{array}{c}0,0 \\
3\end{array}$ & $\begin{array}{c}0,0 \\
6\end{array}$ & $\begin{array}{c}0,0 \\
4\end{array}$ & $\begin{array}{c}0,0 \\
8\end{array}$ & 0,21 & 0,05 \\
\hline $\mathrm{A} 13$ & $\begin{array}{c}0,3 \\
3\end{array}$ & 3,00 & $\begin{array}{c}1,0 \\
0\end{array}$ & $\begin{array}{c}0,2 \\
0\end{array}$ & $\begin{array}{c}0,0 \\
7\end{array}$ & $\begin{array}{c}0,1 \\
7\end{array}$ & $\begin{array}{c}0,1 \\
1\end{array}$ & $\begin{array}{c}0,1 \\
2\end{array}$ & 0,47 & 0,12 \\
\hline Al4 & $\begin{array}{c}3,0 \\
0\end{array}$ & 7,00 & $\begin{array}{c}5,0 \\
0\end{array}$ & $\begin{array}{c}1,0 \\
0\end{array}$ & $\begin{array}{c}0,6 \\
7\end{array}$ & $\begin{array}{c}0,3 \\
9\end{array}$ & $\begin{array}{c}0,5 \\
4\end{array}$ & $\begin{array}{c}0,6 \\
0\end{array}$ & 2,19 & 0,55 \\
\hline$\left(\begin{array}{ll}\Sigma & P_{j}\end{array}\right)$ & $\begin{array}{c}4,4 \\
7\end{array}$ & $\begin{array}{c}18,0 \\
0\end{array}$ & $\begin{array}{c}9,3 \\
3\end{array}$ & $\begin{array}{c}1,6 \\
7\end{array}$ & & & & & & \\
\hline
\end{tabular}

Pengujian konsistensi perbandingan alternatif untuk kriteria Maintainability :

$$
\begin{array}{ll}
\text { Lamda Max } & =1,26+0,93+1,09+0,92=4,20 \\
\mathrm{CI} & =0,07 \\
\mathrm{IR} & =0,90 \\
\mathrm{CR} & =0,07
\end{array}
$$

F. Portability

Tabel 9 Matriks Perbandingan dan Pembobotan Nilai Alternatif untuk Kriteria Portability

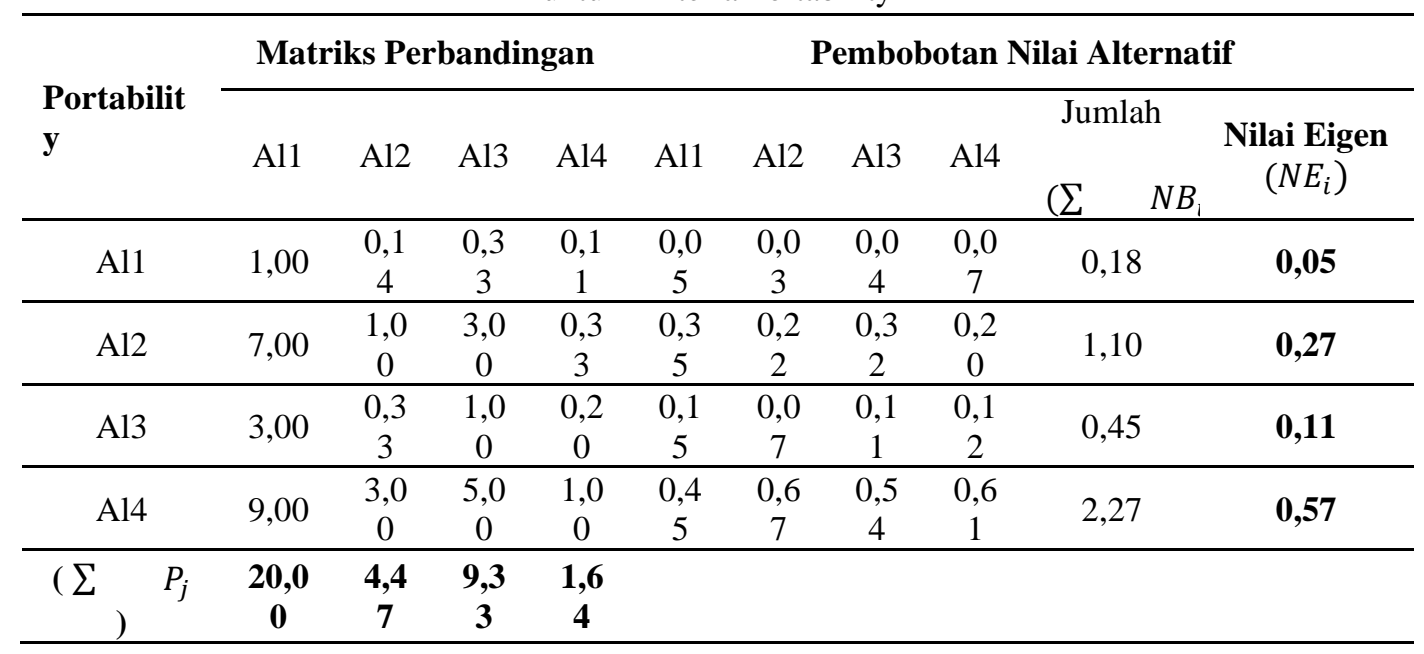

Pengujian konsistensi perbandingan alternatif untuk kriteria Portability :

$$
\begin{array}{ll}
\text { Lamda Max } & =0,92+1,23+1,06+0,93=4,13 \\
\text { CI } & =0,04 \\
\text { IR } & =0,90 \\
\text { CR } & =0,05
\end{array}
$$

\subsection{Perangkingan Alternatif}

Dengan perkalian nilai yang diperoleh setiap alternatif di seluruh kriteria dengan bobot masing-masing kriteria diperoleh rangking alternatif sebagai berikut: 
Tabel 10 Perangkingan Alternatif

\begin{tabular}{lccccccc}
\hline Alternatif & Functionality & Reliability & Usability & Efficiency & $\begin{array}{c}\text { Maintain } \\
\text { ability }\end{array}$ & Portability & Jumlah \\
\hline Dspace & 0,11 & 0,07 & 0,33 & 0,00 & 0,02 & 0,00 & $\mathbf{0 , 5 4}$ \\
\hline Greenstone & 0,02 & 0,01 & 0,02 & 0,02 & 0,00 & 0,01 & $\mathbf{0 , 0 8}$ \\
\hline Eprints & 0,04 & 0,02 & 0,09 & 0,02 & 0,01 & 0,00 & $\mathbf{0 , 1 8}$ \\
\hline SLiMS & 0,01 & 0,01 & 0,09 & 0,03 & 0,04 & 0,02 & $\mathbf{0 , 2 0}$ \\
\hline
\end{tabular}

Dengan demikian Dspace merupakan alternatif rangking pertama berdasarkan prioritas kriteria hasil poling dan penilaian setiap kriteria pada setiap alternatif.

\subsection{Implementasi Alternatif Terpilih}

Implementasi alternatif terpilih dengan melakukan installasi Dspace yang kemudian digunakan untuk pustaka digital oleh Akademi Komunitas Negeri Pacitan.

\section{KESIMPULAN DAN SARAN}

Berdasarkan hasil penerapan teknik AHP dengan kerangka kriteria Software Quality Model untuk memilih software pustaka digital yang paling ideal digunakan di AKN Pacitan, diperoleh bahwa Dspace terpilih sebagai software pustaka digital yang dinilai paling memenuhi kriteria Kebergunaan (Usability), Keberfungsian (Fungsionality) dan Kehandalan (Reliability) sesuai kebutuhan sivitas akademika AKN Pacitan.

Dspace yang terpilih selanjutnya diimplementasikan dengan diintegrasikan ke standar dan dapat dimanfaatkan oleh pustakawan AKN Pacitan sebagai digital repository. Perlu juga disediakan manual untuk penggunaan pustaka digital sehingga pustakawan dan pengakses pustaka digital dapat mudah memahami dan lancar dalam mengoperasikannya. Penelitian yang dilakukan tidak luput dari kekurangan sehingga saran dari pembaca diperlukan demi perbaikan penelitian ini.

\section{DAFTAR PUSTAKA}

[1] M. B. Aulawi, "Pemanfaatan Layanan E-Book Oleh Pemustaka," DIRASAH, vol. 4, no. 1, pp. 134144, 2021.

[2] S. Jayden, "The Best 8 Free and Open Source Library Management Software Solutions," GoodFirms, [Online]. Available: https://www.goodfirms.co/best-free-open-source-library-managementsoftware-solutions".Accessed 42021.

[3] G. N. Pramudyo and M. R. Hendrawan, "PEMILIHAN PERANGKAT LUNAK REPOSITORI INSTITUSI PERPUSTAKAAN PERGURUAN TINGGI DI KOTA MALANG(STUDI KASUS DI PERPUSTAKAAN UNIVERSITAS BRAWIJAYA, PERPUSTAKAAN UNIVERSITAS NEGERI MALANG, DAN PERPUSTAKAAN UNIVERSITAS MUHAMMADIYAH MALANG)," BACA: Jurnal Dokumentasi dan Informasi, vol. 39, no. 2, pp. 161-177, 2018.

[4] D. E. Prayitno, "Perpustakaan Digital Sebagai Information Life Cycle dalam Kehidupan Masyakarat Informasi," Jurnal Ilmu Perpustakaan dan Informasi, vol. 3, no. 2, pp. 23-29, 2019.

[5] H. Magdalena, "MODEL PENGAMBILAN KEPUTUSAN UNTUK MEMILIH SOFTWARE BERBASIS OPEN SOURCE UNTUK APLIKASI DIGITAL LIBRARY BERBASIS WEB," Seminar Nasional Teknologi Informasi dan Komunikasi , pp. 41-48, 2012.

[6] T. Rahman, R. Ferdiana and R. Hartanto, "ANALISIS MODEL PENGAMBIL KEPUTUSAN AHP DAN TOPSIS UNTUK MEMILIH SOFTWARE BERBASIS OPEN SOURCEDIGITAL LIBRARY PADA UNIVERSITAS JANABADRA," in Seminar Nasional Inovasi Teknologi UN PGRI, Kediri, 2017. 
[7] S. Kosasi, "Keputusan Strategis Melakukan Adopsi E-Commerce Menggunakan Analytic Hierarchy Process Strategic Decisions of E-Commerce Adoption Using Analytical Hierarchy Process," Techno.COM, vol. 17, no. 3, pp. 270-280, 2018.

[8] R. Kuswandhie and Y. Primadasa, "Penggabungan Metode MEC dan AHP dalam Penentuan Bantuan Rumah Tidak Layak Huni," Techno.COM, vol. 18, no. 2, pp. 134-144, 2019.

[9] A. Abdullah and M. W. Pangestika, "Perancangan Sistem Pendukung Keputusan Dalam Pemilihan Dosen Pembimbing Skripsi Berdasarkan Minat Mahasiswa dengan Metode AHP (Analytical Hierarchy Process) di Universitas Muhammadiyah Pontianak," JEPIN(Jurnal Edukasi dan Penelitian Informatika), vol. 4, no. 2, pp. 184-191, 2018.

[10] X. Franch, "Using Quality Models in Software Package Selection," IEEE SOFTWARE, pp. 34-41, Jan-Feb 2013.

[11] L. V. T.L. Saaty, Models, Methods, Concepts and Applications of the Analytical Hierarchy Process (Second Edition), New York: Springer, 2012.

[12] B. C. D. D. D. Rimantho, "Application Analytical hierarchy process (AHP) by utilizing the Expert Choice as a tool in decision-making: a case study of e-waste management in Surabaya, Indonesia," in Conference Proceedings 8th International Seminar on Industrial Engineering and Management, Malang, Jawa Timur, 2015.

[13] Lyrasis, "Introduction - $\quad$ Dspace 7," 2021. [Online]. Available: https://wiki.lyrasis.org/display/DSDOC7x/Introduction. [Accessed 2021831 ].

[14] J. Kim, "Finding documents in a digital institutional repository: DSpace and EPrints," in Proceedings of the American Society for Information Science and Technology no. 42 (1), 2005.

[15] Greenstone, "Greenstone Digital Library Software," [Online]. Available: https://www.greenstone.org/. [Accessed 2021831 ].

[16] A.-I. S.-C. P. G.-P. Jesús Tramullas, "An Evaluation Based on the Digital Library User: An Experience with Greenstone Software," in The 2nd International Conference on Integrated Information, 2013.

[17] Eprints, "Eprints - The original institutional repository solution," [Online]. Available: https://www.eprints.org/us/. [Accessed 20218 31].

[18] İ. A. S. Ö. Z. T. S. K. T. Ömer Dalkıran, "Usability Testing of Digital Libraries: The Experience of EPrints," in ICININFO - Procedia - Social and Behavioral Sciences 147 ( 2014 ) 535 - 543, 2014.

[19] SLiMS, "SLiMS - Senayan Library Managements Sistem," [Online]. Available: https://slims.web.id/web/pages/about/. [Accessed 20218 31].

[20] W. A. K. P. M. Danang Dwijo Kangko, "USABILITY TESTING PADA ANTARMUKA KATALOG DARING SLIMS 8.0 AKASIA DI PERPUSTAKAAN BNPB," Jurnal Pustakawan Indonesia, vol. 16, no. 2, pp. 20-28, 2017. 